Determinants of Commercial Bank Interest Margins and Profitability

Some International Evidence

Asl1 Demirgüç-Kunt

Harry Huizinga
Differences in interest margins

reflect differences in bank

characteristics, macro-

economic conditions, existing

financial structure and

taxation, regulation, and

other institutional factors.

The World Bank

Development Research Group

March 1998 
Policy Research Working Paper 1900

\section{Summary findings}

Using bank data for 80 countries for 1988-95, Demirgüç-Kunt and Huizinga show that differences in interest margins and bank profitability reflect various determinants:

- Bank characteristics.

- Macroeconomic conditions.

- Explicit and implicit bank taxes.

- Regulation of deposit insurance.

- General financial structure.

- Several underlying legal and institutional indicators. Controlling for differences in bank activity, leverage, and the macroeconomic environment, they find (among other things) that:

- Banks in countries with a more competitive banking sector - where banking assets constitute a larger share of GDP - have smaller margins and are less profitable. The bank concentration ratio also affects bank profitability; larger banks tend to have higher margins.

- Weli-capitalized banks have higher net interest margins and are more profitable. This is consistent with the fact that banks with higher capital ratios have a lower cost of funding because of lower prospective bankruptcy costs.

- Differences in a bank's activity mix affect spread and profitability. Banks with relatively high noninterest- earning assets are less profitable. Also, banks that rely largely on deposits for their funding are less profitable, as deposits require more branching and other expcnses. Similarly, variations in overhead and other operating costs are reflected in variations in bank interest margins, as banks pass their operating costs (including the corporate tax burden) on to their depositors and lenders.

- In developing countries foreign banks have greater margins and profits than domestic banks. In industrial countries, the opposite is true.

- Macroeconomic factors also explain variation in interest margins. Inflation is associated with higher realized interest margins and greater profitability. Inflation brings higher costs - more transactions and generally more extensive branch networks - and also more income from bank float. Bank income increases more with inflation than bank costs do.

- There is evidence that the corporate tax burden is fully passed on to bank customers in poor and rich countries alike.

- Legal and institutional differences matter. Indicators of better contract enforcement, efficiency in the legal system, and lack of corruption are associated with lower realized interest margins and lower profitability.

This paper - a product of the Development Research Group - is part of a larger effort in the group to study bank efficiency. Copies of the paper are available free from the World Bank, $1818 \mathrm{H}$ Street NW, Washington, DC 20433. Please contact Paulina Sintim-Aboagye, room MC3-422, telephone 202-473-7656, fax 202-522-1155, Internet address ademirguckunt@woridbank.org. March 1998.(48 pages)

The Policy Research Working Paper Series disseminates the findings of work in progress to encourage the exchange of ideas about development issues. An objecinie of the series is to get the findings out quickly, even if the presentations are less than fully polished. The papers cary the names of the authors and should be cited accordingly. The findings, interpretations, and conclusions expressed in this paper are entively those of the authors. They do not necessarily represent the view of the World Bank, its Executive Directors, or the countries they represent. 


\title{
Determinants of commercial bank interest margins and profitability: some international evidence
}

\author{
Aslı Demirgüç-Kunt and Harry Huizinga ${ }^{1}$
}

Keywords: bank profitability, taxation, financial structure JEL Classification: E44, G21

\footnotetext{
${ }^{1}$ Development Research Group, The World Bank, and Development Research Group, The World Bank and CentER and Department of Economics, Tilburg University, respectively. The findings, interpretations, and conclusions expressed in this paper are entirely those of the authors. They do not necessarily represent the views of the World Bank, its Executive Directors, or the countries they represent. We thank Jerry Caprio, George Kaufman, Mary Shirley and 1998 AEA session participants for comments and suggestions. We also thank Anqing Shi for excellent research assistance and Paulina Sintim-Aboagye for help with the manuscript.
} 


\section{Introduction}

As financial intermediaries, banks play a crucial role in the operation of most economies. Recent research, as surveyed by Levine (1996), has shown that the efficacy of financial intermediation can also affect economic growth. Crucially, financial intermediation affects the net return to savings, and the gross return for investment. The spread between these two returns mirrors the bank interest margins, in addition to transaction costs and taxes borne directly by savers and investors. This suggests that bank interest spreads can be interpreted as an indicator of the efficiency of the banking system. In this paper, we investigate how bank interest spreads are affected by taxation, the structure of the financial system, and financial regulations such deposit insurance.

A comprehensive review of determinants of interest spreads is offered by Hanson and Rocha (1986). That paper summarizes the role that implicit and explicit taxes play in raising spreads and goes on to discuss some of the determinants of bank cost and profits, such as inflation, scale economies, and market structure. Using aggregate interest data for 29 countries in the years 1975-1983, the authors find a positive correlation between interest margins and inflation.

Recently, several studies have examined the impact of international differences in bank regulation using cross-country data. Analyzing interest rates in 13 OECD countries in the years 1985-1990, Bartholdy, Boyle, and Stover (1997) find that the existence of explicit deposit insurance lowers the deposit interest rate by 25 basis points. Using data from 19 developed countries in 1993, Barth, Nolle and Rice (1997) further examine the impact of banking powers on bank return on equity - controlling for a variety of bank 
and market characteristics. Variation in banking powers, bank concentration and the existence of explicit deposit insurance do not significantly affect the return on bank equity.

This paper extends the existing literature several ways. First, using bank-level data for 80 developed and developing countries in the 1988-1995 period, we provide summary statistics on size and decomposition of bank interest margins and profitability. Second, we use regression analysis to examine the underlying determinants of interest spreads and bank profitability. The empirical work enables us to infer to what extent the incidence of taxation and regulation is on bank customers and/or the banks themselves. Apart from covering many banks in many countries, this study is unique in its coverage of interest margin and profitability determinants. These determinants include a comprehensive set of bank characteristics (such as size, leverage, type of business, foreign ownership), macro indicators, taxation and regulatory variables, financial structure variables, and legal and institutional indices. Among these, the ownership variable, the tax variables, some of the financial structure variables, and the legal and institutional indicators have not been included in any previous study in this area. To check whether some of these determinants affect banking differently in developing and developed countries, we further interact these variables with the country's GDP per capita.

The results indicate that bank characteristics, macro indicators, implicit and explicit financial taxation, deposit insurance, overall financial structure, and the legal and institutional environment all significantly affect bank interest spreads and profitability. 
Our results show that well-capitalized banks have higher net interest margins and are more profitable. This is consistent with the fact that banks with higher capital ratios tend to face a lower cost of funding due to lower prospective bankruptcy costs. In addition, a bank with higher equity capital simply needs to borrow less in order to support a given level of assets.

Differences in the bank activity mix also have an impact on spreads and profitability. Our results show that banks with relatively high non-interest earning assets are less profitable. Also, banks that rely largely on deposits for their funding are less profitable, as deposits apparently require high branching and other expenses. Similarly, variation in overhead and other operating costs is reflected in variation in bank interest margins, as banks pass on their operating costs to their depositors and lenders.

The international ownership of banks also has a significant impact on bank spreads and profitability. Foreign banks, specifically, realize higher interest margins and higher profitability than domestic banks in developing countries. This finding may reflect that in developing countries a foreign bank's technological edge is relatively strong, apparently strong enough to overcome any informational disadvantage. Foreign banks, however, are shown to be less profitable in developed countries.

Macroeconomic factors also explain variation in interest margins. We find that inflation is associated with higher realized interest margins and higher profitability. Inflation entails higher costs - more transactions, and generally more extensive branch networks - and also higher income from bank float. The positive relationship between inflation and bank profitability implies that bank income increases more with inflation 
than bank costs. Further, high real interest rates are associated with higher interest margins and profitability, especially in developing countries. This may reflect that in developing countries demand deposits frequently pay zero or below market interest rates.

Banks are subject to implicit and explicit taxation which may affect their operations. Implicit taxes include reserve and liquidity requirements that are remunerated at less-than-market rates. ${ }^{2}$ We find that reserves reduce interest margins and profits especially in developing countries, since there the opportunity cost of holding reserves tends to be higher and remuneration rates are lower. Explicit taxes translate into higher net interest margins and bank profitability. In fact, the regression coefficients suggest that the corporate tax is fully passed on to bank customers in poor and rich countries alike, and is not simply a tax on bank rents. This result is consistent with the common notion that bank stock investors need to receive a net-of-company-tax return that is independent of this company tax.

The existence of an explicit deposit insurance scheme coincides with lower interest margins. The effect on bank profitability is also negative, although it is not significant. These results may reflect design and implementation problems inherent in explicit deposit insurance systems.

Regarding financial structure, banks in countries with a more competitive banking sector -- where banking assets constitute a larger portion of the GDP -- have smaller margins and are less profitable. The bank concentration ratio positively affects bank

\footnotetext{
${ }^{2}$ Directed and subsidized credit practices that interfere with the banks' credit allocation policies represent additional implicit taxes. However, due to lack of data for most of the countries in our sample we do not evaluate the impact of such practices here.
} 
profitability, and larger banks tend to have higher margins. A larger stock market capitalization to GDP increases bank margins, reflecting possible complementarity between debt and equity financing. A larger stock market capitalization to bank assets, however, is related negatively to margins, suggesting relatively well-developed stock markets can substitute for bank finance.

Finally, we find that legal and institutional differences matter. Indicators of better contract enforcement, efficiency of the legal system and lack of corruption are associated with lower realized interest margins and lower profitability.

Section 2 next describes the basic approach of this study. Section 3 discusses the data. Section 4 presents the empirical results. Section 5 concludes.

\section{Investigating banking spreads and profitability}

The efficiency of bank intermediation can be measured by both ex ante and ex post spreads. Ex ante spreads are calculated from the contractual rates charged on loans and rates paid on deposits. Ex post spreads consist of the difference between banks' interest revenues and their actual interest expenses. The ex ante measures of spread are biased to the extent that differences in perceived risks are reflected in the ex ante yields. Since bearing of risk is an important dimension of banking services, any differences in the risks faced by bankers will tend to distort spread comparisons. An additional problem with using ex ante spread measures is that data are generally available at the aggregate industry level and are put together from a variety of different sources and thus are not 
completely consistent. For these reasons, we focus on ex post interest spreads in this paper. $^{3}$

As a measure of bank efficiency, we consider the accounting value of a bank's net interest income over total assets, or the net interest margin. To reflect bank profitability, we consider the bank's before-tax profits over total assets, or before tax profit/ta. By straightforward accounting, before tax profit/ta is the sum of after-tax profits over total assets, or net profit/ta, and taxes over total assets, or tax/ta. From the bank's income statement, before tax profit/ta further satisfies the following accounting identity:

$$
\begin{aligned}
\text { before tax profit/ta }= & \text { net interest margin }+ \text { non-interest income/ta }- \text { overhead/ta } \\
& - \text { loan loss provisioning/ta }
\end{aligned}
$$

where the non-interest income/ta variable reflects that many banks also engage in nonlending activities, such as investment banking and brokerage services; the overhead/ta variable accounts for the bank's entire overhead associated with all its activities, while loan loss provisioning/ta simply measures actual provisioning for bad debts.

While net interest margin can be interpreted as a rough index of bank (in)efficiency, this does not mean that a reduction in net interest margins always signals improved bank efficiency. To see this, note that a reduction in net interest margins can, for example, reflect a reduction in bank taxation or, alternatively, a higher loan default

\footnotetext{
${ }^{3}$ A problem with ex post spreads, however, is that the interest income and loan loss reserving associated with a particular loan tend to materialize in different time periods. Due to differences in nonperforming loans/or monitoring costs associated with loan quality, these spreads may not reflect efficiency differences accurately.
} 
rate. In the first instance, the reduction in net interest margins reflects an improved financial market function, while in the second case the opposite may be true. Also, note that variation in an accounting ratio such as net interest margin may reflect differences in net interest income (the numerator) or differences in (say) non-lending assets (in the denominator). The data used have been converted to common international accounting standards as far as possible. All the same, there may still be some remaining differences in accounting conventions regarding the valuation of assets, loan loss provisioning, hidden reserves, etc. ${ }^{4}$

This study focuses on accounting measures of income and profitability, as (riskadjusted) financial returns on bank stocks are equalized by investors in the absence of prohibitive barriers. For this same reason, Gorton and Rosen (1995) and Schranz (1993) also focus on accounting measures of profitability when examining managerial entrenchment and bank takeovers.

The above accounting identity suggests a useful decomposition of realized interest spreads, i.e. net interest margin, into its constituent parts, i.e. into non-interest income, overhead, taxes, loan loss provisions, and after-tax bank profits. This approach, with some modifications, is taken in the study by Hanson and Rocha (1986). As a first step to analyzing the data, section 3 of the paper provides an accounting breakdown of the net interest variable, net interest margin, for individual countries and for selected aggregates. While it may be misleading to compare accounting ratios without controlling for differences in the macroeconomic environment the banks operate in and the differences in

\footnotetext{
${ }^{4}$ See Vittas (1991) for an account of the pitfalls in interpreting bank operating ratios.
} 
their business, product mix, and leverage, these breakdowns still provide a useful initial assessment of differences across countries.

Next, controlling for bank characteristics and the macro environment, we provide an economic analysis of the determinants of the interest and profitability variables, net interest margin, and before tax profit/ta. This empirical work also provides insights as to how bank customers and the banks themselves are affected by these variables. The net interest margin regressions specifically tell us how the combined welfare of depositors and lenders is affected by the spread determinants. The relationship between the interest spread variable and a bank's corporate taxes, for instance, informs us to what extent a bank is able to shifts its tax bill forward to its depositors and lenders. Next, the before tax profit/ta regressions give information on how spread determinants affect bank shareholders. Equivalently, the relationship between bank profitability and bank corporate income taxes reflects to what extent a bank can pass on its tax bill to any of its customers, depositors, lenders or otherwise. ${ }^{5}$

The subsequent regression analysis starts from the following basic equation:

$$
I_{i j t}=\alpha_{o}+\alpha_{i} B_{i t}+\beta_{j} X_{j t}+\gamma_{t} T_{t}+\delta_{j} C_{j}+\varepsilon_{i j t}
$$

\footnotetext{
${ }^{5}$ Generally, taxes and other variables can change interest rates as well as quantity variables, i.e. loan and deposit volumes. In the short term, the major effects may come through pricing changes, in which case net interest margin and before tox profit/ta immediately yield easily interpreted welfare consequences for the banks and their customers. With market imperfections in the form of credit rationing or imperfect competition in the credit markets, changes in quantities generally have first order welfare implications independently of changes in prices. Quantity changes, however, are not pursued in the empirical work.
} 
where $I_{i j t}=$ is the independent variable (either net interest margin or before tax profits/ta) for bank $i$ in country $j$ at time $t ; B_{i j t}$ are bank variables for bank $i$ in country $j$ at time $t ; X_{j t}$ are country variables for country $j$ at time $t$; and $T_{t}$ and $C_{j}$ are time and country dummy variables. Further, $\alpha_{o}$ is a constant, and $\alpha_{i j} \beta_{j}, \gamma_{t}$ and $\delta_{j}$ are coefficients, while $\varepsilon_{i j t}$ is an error term. Several specifications of (2) are estimated that differ in which bank and country variables are included.

\section{The data}

This study uses income statement and balance sheet data of commercial banks from the BankScope data base provided by IBCA (for a complete list of data sources and variable definitions, see the Appendix). Coverage by IBCA is very comprehensive in most countries, with banks included roughly accounting for 90 percent of the assets of all banks. We started with the entire universe of commercial banks worldwide, with the exception that for France, Germany and the United States only several hundred commercial banks listed as 'large' were included. To ensure reasonable coverage for individual countries, we included only countries where there were at least three banks in a country for a given year. This yielded a data set covering 80 countries during the years 1988-1995, with about 7900 individual commercial bank accounting observations. This data set includes all OECD countries, as well as many developing countries and economies in transition. For a list of countries, see Table 1.

Table 1 provides country averages of interest spreads and bank profitability.

Column 1 provides information on net interest income over assets, or net interest margin, 
as a percentage. At the low end, there are several developed countries, Luxembourg and the Netherlands, and Egypt with a net interest margin of about 1 percent. For the case of Egypt, the low net interest margin can be explained by a predominance of low-interest directed credits by the large state banking sector. Generally, developing countries, and especially Latin American countries such as Argentina, Brazil, Costa Rica, Ecuador and Jamaica, display relatively large accounting spreads. This is also true for certain Eastern European countries such as Lithuania and Romania. Columns 3 though 6 provide an accounting breakdown of the net interest income into its four components: overhead minus non-interest income, taxes, loan loss provisioning, and net profits, all divided by net interest income. These shares add to one hundred percent except for cases where information on loan loss provisioning is missing.

The $t a x / n i$ variable reflects the explicit taxes paid by the banks (mostly corporate income taxes). Banks also face implicit taxation due to reserve and liquidity requirements and other restrictions on lending through directed/subsidized credit policies. These indirect forms of taxing banks show up directly in lower net interest income rather than in its decomposition. Nonetheless, the $t a x / n i$ variable indicates that there is considerable international variation in the explicit taxation of commercial banks. Several countries in Eastern Europe (for example Lithuania, Hungary and the Czech Republic) impose high explicit taxes on banking. The lowest value of tax/ni is at 0 for Qatar, in the absence of significant taxation of banking. For some countries, such as Norway, Sweden or Costa Rica, low tox/ni values reflect the tax deductibility of plentiful bad debts. 
The loan loss provisioning/ni variable is a direct measure of difference in credit quality across countries and it also reflects differences in provisioning regulations. This variable is high for some Eastern European countries. The loan loss provisioning/ni variable is also high for some developed countries such as France and the Nordic countries. As a residual, the net profits/ni variable reflects to what extent the net interest margin translates into net-of-tax profitability.

Columns $7-11$ of Table 1 further tabulate the various accounting ratios (relative to total assets) in the accounting identity (1) presented above. The non-interest income/ta variable reveals the importance of fee-based services for banks in different countries. Banks in Eastern Europe, for example in Estonia, Hungary, and Russia, seem to rely heavily on fee-based operations. This is also the case in some Latin American countries, such as, Argentina, Brazil, Colombia, Peru and a few African countries as in Nigeria, and Zambia.

The overhead/ta variable provides information on variation in bank operating costs across banking systems. This variable reflects variation in employment as well as in wage levels. Despite high wages, the overhead/ta variable appears to be lowest at around 1 percent for high-income countries, such as Japan and Luxembourg. The overhead/ta cost measure is notably high at 3.6 percent for the United States, perhaps reflecting the proliferation of banks and bank branches due to banking restrictions. In the $t a x / t a$ column, Jamaica, Lithuania, and Romania stand out with high tax-to-assets ratios of around 2 percent. Loan loss provisioning, proxied by loan loss provisioning/ta, is equally 
high in Eastern Europe, and in some developing countries. Finally, net profits over assets, or net profit/ta, also tends to be relatively high in developing countries.

In Table 2 we present statistics on accounting spreads and profitability for selected aggregates. The first breakdown is by ownership; a bank is said to be foreignowned if fifty percent or more of its shares is owned by foreign residents. The table displays a rather small difference in the net interest margin variable for domestic banks (at 3.7 percent) and foreign banks (at 2.9 percent). This small difference, however, masks that foreign banks tend to achieve higher interest margins in developing countries, and lower interest margins in developed countries. ${ }^{6}$ These facts may reflect that foreign banks are less subject to credit allocation rules and have technical advantages (in developing countries), but also have distinct informational disadvantages relative to domestic banks (everywhere).

Interestingly, foreign banks pay somewhat lower taxes than domestic banks (as indicated by the $t a x / t a$ variable). This difference may reflect different tax rules governing domestic and foreign banks, but also foreign banks' opportunities to shift profits internationally to minimize their global tax bill. Foreign banks also have a relatively low provisioning as indicated by loan loss provisioning/ta, which is consistent with the view that foreign banks generally do not engage in retail banking operations.

The next breakdown in the table is by bank size. For countries with at least 20 banks, large banks are defined as the 10 largest banks by assets. Large banks tend to have

\footnotetext{
${ }^{6}$ See Claessens, Demirgüç-Kunt and Huizinga (1997) for more detailed information on the average spreads of domestic and foreign banks for different groupings of countries by income. This paper also considers how entry by foreign banks affects the interest spreads and operating costs of domestic banks.
} 
lower margins and profits and smaller overheads. They also pay relatively low direct taxes, and have lower loan loss provisioning.

The table also considers bank groupings by national income levels and location. Analyzing data on 4 income levels, we see that the net interest margin is highest for the middle income groups. Banks in the middle income group also have the highest values for the overhead/ta, tax/ta, and loan loss provisioning/ta variables. The net profit/ta variable tends to be highest for banks in the lower income groups. Banks in the high income group, instead, achieve the lowest net interest margin, and they face the lowest ratios of overhead, taxes, loan loss provisioning, and net profits to assets.

Next, the breakdown by regions reveals that the net interest margin is highest in the transitional economies at 6.4 percent, and also rather high in Latin America at 6.2 percent, while it is the lowest for industrialized countries at 2.7 percent. The transitional countries further stand out with high ratios of overhead, taxes, loan loss provisioning, and net profits to assets. Industrialized countries, have the lowest net profit/ta value at 0.4 percent, probably due to high level of competition in banking services. Figures 1 and 2 also illustrate income decomposition for different regions.

Table 3 provides information on some of the macroeconomic and institutional indicators used in the regression analysis. The data is for 1995, or the most recent year available. The tox rate variable is computed on a bank-by-bank basis as taxes paid divided by before-tax profits. The figure reported in the table is the average for all banks in the country in 1995. The reserves/deposits variable is defined as the banking system's

\footnotetext{
${ }^{7}$ For country groupings by income, see the World Development Report (1996). Countries in transition are China, the Czech Republic, Estonia, Hungary, Lithuania, Poland, Romania, Russia, and Slovenia.
} 
aggregate central bank reserves divided by aggregate banking system deposits. Actual reserve holdings reflect required as well as excess reserves. Reserves are generally remunerated at less-than-market rates, and therefore actual reserves may be a reasonable proxy for required reserves, as averaged over the various separate deposit categories. For several developing countries, Botswana, Costa Rica, El Salvador, Jordan, and for Greece, the reserves ratio is above 40 percent, indicating substantial financial repression. In contrast, this ratio is rather low in Belgium, France and Luxembourg at 0.01 .

The deposit insurance variable is a dummy variable that takes on a value of one if there is an explicit deposit insurance scheme (with defined insurance premia and insurance coverage), and a value of zero otherwise. Even for the case of an explicit deposit insurance scheme, however, the ex post insurance coverage may prove to be higher than the de jure coverage, if the deposit insurance agency chooses to guarantee all depositors. With a value of zero, there is no explicit deposit insurance, even if there may be some type of implicit insurance by the authorities.

Next, the table presents some indicators of financial market structure. The concentration variable is defined as the ratio of the three largest banks' assets to total banking sector assets. As is well known, the concentration of the U.S. banking market is rather low, at a value of 16 percent, compared to values of about 50 percent for France and Germany. ${ }^{8}$ The number of banks in the table reflects the number of banks in the data set with complete information. The bank/gdp ratio defined as the total assets of the deposit money banks divided by GDP. This ratio reflects the overall level of development

\footnotetext{
${ }^{8}$ The U.S. figure may understate the the concentration ratio in individual banking markets, as protected from outside competition by banking restrictions.
} 
of the banking sector. The next variable, $m c a p / g d p$ is the ratio of stock market capitalization to GDP, as a measure of the extent of stock market development. Developing countries tend to have lower $b a n k / g d p$ and $m c a p / g d p$ ratios, with some notable exceptions. Malaysia, South Africa and Thailand, for instance, have relatively high ratios for both variables.

The final column in the table provides an index of law and order, which is one of the institutional variables used in the regression analysis. This variable is scaled from 0 to 6, with higher scores indicating sound political institutions and strong court system. Lower scores, in contrast, reflect a tradition where physical force or illegal means are used to settle claims. The table reflects that there is considerable variation in legal effectiveness among countries in the sample.

\section{Empirical results}

This section presents regression results. Table 4 and Table 5 report the results of regressions of the net interest margin and before tax profit/ta variables, respectively. All regressions include country and year fixed effects. The tables include several specifications, with the basic specification including a set of bank-level variables, and macroeconomic indicators as regressors. These are important control variables which we include in all specifications. Subsequently, we add the taxation variables, the deposit insurance index, financial structure variables, and legal and institutional indicators. The deposit insurance index, is again excluded from the specification in columns 4 and 5 , while the financial structure variables are excluded from the specification in column 5. 
The reason for dropping some variables from regressions 4 and 5 is that we wish to ensure that banks from a reasonable number of countries is included in the regressions. The estimation technique is weighted least squares, with the weight being the inverse of the number of banks for a the country in a given year. This weighing corrects for the fact that the number of banks varies considerably across countries. The five specifications in the two tables are discussed in each of the five subsections.

\subsection{Bank characteristics and macroeconomic indicators}

The first bank characteristic is book value of equity divided by total assets lagged one period, or equity/tat ${ }_{t-1}^{9}$ Previously, Buser, Chen and Kane (1981) have examined the theoretical relationship between bank profitability and bank capitalization. These authors find that banks generally have an interior optimal capitalization ratio in the presence of deposit insurance. Generally, banks with a high franchise value - reflecting costly bank entry - have incentives to remain well-capitalized and to engage in prudent lending behavior (see Caprio and Summers (1993), and Stiglitz (1996)). Berger (1995) provides empirical evidence that for U.S. banks there is a positive relationship between bank profitability and capitalization. The author notes that well-capitalized firms face lower expected bankruptcy costs for themselves and their customers, thereby reducing their cost of funding.

The first columns in Table 4 and 5 confirm a positive relationship between the equity/ta ${ }_{t-1}$ variable and net interest income and bank profitability. In the regressions, the

\footnotetext{
${ }^{9}$ The lagging is to correct for the fact that profits - if not paid out in dividends - have a contemporaneous impact on bank equity.
} 
equity/ta ${ }_{t-1}$ variable is also interacted with GDP per capita (measured in units of constant $\$ 1,000$ dollars for the year 1987 ). The positive coefficient on the interaction variables in the before tax profit/ta regression can reflect a higher bank franchise value in wealthier countries. The coefficients for the equity/t $a_{t-1}$ variable and the interaction with per capita GDP together indicate how the equity/assets ratio affects the bank variables in countries with different income levels. For a country with a per capita GDP of $\$ 10,000$, for instance, the point estimate of the effect of the equity/tat $t_{t-1}$ variable on before tax profit/ta is 0.067 (or $0.047+10 \times 0.002$ ).

Next, there is a negative and significant coefficient on the non-interest earning assets/ta variable in the net interest margin equation, but there is no significant relationship for the before tax profit/ta equation. Note that the sign on the non-interest earning assets/ta variable interacted with per capita GDP is negative in both the net interest margin and the before tax profit/ta specifications. Apparently, in wealthier countries the presence of non-interest earning assets depresses net interest income and profitability more than in poorer countries. By contrast, the sign on loan/ta variable is positive in the net interest margin equation and negative in the before tax profit/ta equation. However, the coefficient of the variable interacted with GDP in the profit equation is positive, indicating that at higher income levels banks' lending activities tend to be more profitable.

On the liability side, customer and short-term funding consists of demand deposits, savings deposits and time deposits. On average, this type of customer funding may carry a low interest cost, but it is costly in terms of the required branching network. 
In Table 4, we see that this liability category does not significantly affect the net interest variable, while in Table 5 there is some evidence that it lowers bank profitability.

Differences in overhead may also capture differences in bank business and product mix, as well as the variation in the range and quality of services. The overhead to assets ratio variable, overhead/ta, has an estimated coefficient of 0.173 in the net interest margin regression, which suggests that about a sixth of a bank's overhead cost is passed on to its depositors and lenders. The interaction of the overhead/ta variable with per capita GDP also enters with a positive coefficient, indicating there is a larger share of overhead passed on to financial customers in wealthier countries. This may reflect more competitive conditions in developed country banking markets than in the developing countries. In the before tax profit/ta regression the interaction of the overhead/ta variable with per capita GDP enters negatively indicating that higher overheads eat into bank profits.

The foreign ownership variable equals one, if at least 50 percent of the bank's stock is in foreign hands and it is zero otherwise. In both Tables 4 and 5 , the foreign ownership variable has a positive coefficient, while its interaction with per capita GDP has a negative coefficient. This suggests that foreign banks realize relatively high net interest margins and profitability in relatively poor countries. This may reflect that foreign banks are frequently exempt from unfavorable domestic banking regulations, and may apply superior banking techniques. Note that the point estimate of the foreign ownership effect in the net interest margin equation for a wealthy country with a per capita GDP of $\$ 20,000$, however, is negative at -0.016 (i.e., $0.004-20 \times 0.001$ ), as is the 
effect on profitability at -0.015 (i.e., $0.005-20 \times 0.001$ ). Foreign banks' technological and efficiency advantages in developed countries may be insignificant, while there they do face informational disadvantages. This can explain that on net foreign banks in developed countries are relatively unprofitable.

Next, we turn to the macro indicators in the regressions. First, per capita GDP has no significant impact on realized net interest margins, while this variable enters with a positive coefficient in the profitability equation. The per capita GDP is a general index of economic development, and thus it reflects differences in banking technology, the mix of banking opportunities, and any aspects of banking regulations omitted from the regression. Growth, defined as the growth rate of per capita real GDP, is insignificant in both spread and profit regressions. The percentage change in the GDP deflator, or inflation, is estimated to increase the net interest margin and bank profitability, although significance of the coefficients in the profitability regressions is low. This may reflect that banks obtain higher earnings from float, or the delays in crediting customer accounts, in an inflationary environment. With inflation, bank costs generally also rise. A larger number of transactions may lead to higher labor costs, and as shown by Hanson and Rocha (1986, p. 40), result in a higher bank branch per capita ratio. On net, however, the regression results suggest that the impact of inflation on profitability, while not very significant, is positive throughout.

The real interest rate is constructed using the short-term government debt yield, and where not available, other short term market rates. The real interest variable enters the net interest margin and before tax profit/ta regressions positively in Table 4 and 
